\title{
Comparative analysis of socialist and bourgeois art in the social philosophical aspect
}

\author{
Alla Matveeva*, Roman Krasnov, Ekaterina Yalunina, and Andrey Romanov \\ Ural State University of Economics, 620144, Yekaterinburg, Russia
}

\begin{abstract}
At the beginning of the XX century, bourgeois theorists of artistic culture declared dehumanization as one of the main features of the modernism art, one of the main tasks of the contemporary artists' artwork. Getting to the scientific understanding of the complex and complicated phenomena of modern art culture, it is necessary to reveal not only the socio-economic reasons for their appearance; the philosophical prerequisites for the development of modern bourgeois art, the ideological orientation of its movements should be identified. In the article, the authors argue that modern bourgeois aesthetics objectively performs the opposite tasks: a) bourgeois art distracts artists and spectators from pressing issues of life, b) imposes ideals and tastes that are advantageous to the bourgeoisie, c) sow pessimism and disbelief in human forces. According to authors, as opposing the personality of society, bourgeois art contributes to the isolation of human from social problems, from issues and tasks of the struggle for a better future. The authors believe that the disclosure of the reactionary ideological essence for the many directions of modern bourgeois art enables a consistent Marxist aesthetic analysis of the content and form of artwork and the principles of bourgeois artists' creativity. Naturally, the philosophical idealist teachings and aesthetic systems that make up the theoretical foundation of modern bourgeois art, embodied in its various directions not directly but indirectly. Only a Marxist analysis of artistic phenomena and techniques of artistic creation in their correlation with the creative method makes it possible to reveal the true interconnections of these phenomena and the essence of artistic techniques, makes it possible to detect and criticize scientifically based falsification ideas of bourgeois theoreticians of art.
\end{abstract}

\section{Introduction}

Art is an integral part of people's lives. Rapid scientific and technological progress has opened up hitherto unprecedented opportunities for the dissemination of culture. With the growth of mass communication media, the flow of information increases, including it's most diverse aspects, such as the philosophical and aesthetic aspects. The Internet, cinema, television have a strong impact on the human personality, shaping a person in accordance

\footnotetext{
* Corresponding author: matveevaa2011@yandex.ru
} 
with social, ideological, ethical, cultural and philosophical social ideals, but in the routine of informational innovations we must not forget that "any socio-economic development is characterized by its own type of spiritual production, determined by the method of material production inherent in this development".

"The bourgeois culture of the West cannot be represented as the only and comprehensive phenomenon; in capitalist countries it is opposed by a democratic culture that reflects the genuine interests of the working class and the working masses" (Lapoktysh, 1984). This culture is upheld and supported by the Marxist-Leninist communist and workers parties, all progressive forces. That is precisely why bourgeois theoretical thought is increasingly witnessing attempts to equate the socialist culture of the masses, which bears the idea of humanism and encourages people to be creative and bourgeois "mass culture" whose goal is to manipulate the minds of millions of people.

Socialist art, Marxist-socialist aesthetics, having scientific dialectical materialistic philosophical foundations, affirm advanced humanistic social aesthetic ideals. Our art and aesthetics help to know life, actively influence it; Being focused on raising the general cultural level of people, they are an effective means of forming a comprehensively developed personality of a person in a communist formation.

\section{Wording of the problem}

When writing the article, the authors pursued one goal to prove that:

1) Modern bourgeois aesthetics objectively performs opposite tasks: bourgeois art distracts artists and spectators from pressing issues of life, imposes ideals and tastes that are advantageous to the bourgeoisie, and sows pessimism and disbelief in human powers.

2) Contrasting personality with society, bourgeois art promotes the isolation of human from social problems, from the issues and tasks of the struggle for a better future.

3) Reveal the reactionary ideological essence of the many directions of modern bourgeois art makes it possible for a consistent Marxist aesthetic analysis of the content and form of artistic works and the principles of creativity of bourgeois artists.

\section{Research Methods}

The methodological basis of the article is the principles of integrity, objectivity and historicism.

\section{Cases and their research}

The modern art of the West, generated by the era of imperialism, is known as modernism. The introduction of the term "modernism", as an analysis of art generated by the era of imperialism, allows us to identify features that distinguish it from the decadent art of the late XIX - early XX centuries, which, although it contained elements of formalism, was not devoid of meaningful content and has not lost communicativeness.

Using the term "modernism" in a Marxist analysis of contemporary bourgeois art, one should avoid expanding the scope of the concept and not designate contemporary art as a whole; "Modernism" is a local definition of the totality for contemporary art trends based on the formalism method. The appearance of incomprehensible works of art at the beginning of the century was a surprise to the audience and caused an acute reaction among art lovers, mainly outrage. "... New art meets a mass opposed to it, and will always be faced with it. It is unpopular in its very essence; moreover, it is anti-popular ... Accustomed to take the upper hand in everything, the mass feels offended in its "human feelings" by new 
art ... Every place where young muses appear, the mass resist them "(Jose Ortega y Gasset, 1950, p.354), wrote the Spanish philosopher José Ortega y Gasset about the first exhibitions of modernism.

Many philosophers of that time directly or indirectly influenced the bourgeois art development of the 20th century. The extreme pessimism of these (and similar) philosophers in assessing human reason and progress, and extreme subjectivity did not correspond to the mood of the minds for the first half of the XIX century: too many still believed in the possibility of the progressive development of bourgeois society, hoping for the realization of humanistic ideals within this society. However, as the crisis deepened in bourgeois society in the second half of the XIX century these moods began to change, resulting in a sharp increase in demand for idealistic philosophical literature. It was during this period that the works of A. Schopenhauer were republished and translated into European languages, the ideas of which were used and developed in the works of bourgeois philosophers of the next generation, primarily F. Nietzsche and A. Bergson.

A little later, in the first quarter of the XX century, the works of S. Kierkegaard were published in German, which became one of the ideological sources of the philosophy of existentialism (Egorov, 1961, pp. 108-132). The philosophical arsenal of ideologists of the bourgeoisie was replenished with the works of E. Hartmann ("The Philosophy of the Unconscious"), O. Spengler ("The Sunset of Europe"), B. Croce, and most importantly, the teachings of Z. Freud, which significantly influenced the fate of bourgeois art of the XX century.

Escalated in the second half of the XIX century the struggle of philosophical idealism and materialism was reflected in the field of art theory and practice.

However, these areas, which aspired to be innovative, did not yet call into question, and even more so did not try to deny centuries-old traditions of artistic creation. To a greater or lesser extent, artists of these directions retained in their work the principle of reflection by art of reality, the principle of communicativeness. Often far from pressing social problems, their desire for innovation was directed, rather, against orthodox, so-called academic, art, rather than against the established laws of artistic creation. The creative techniques used by artists to create "non-academic" works were very diverse and ranged from critical realism (which served as an effective means of exposing the vices of bourgeois society) to the formalistic techniques by which the artist tried to express his individual protest to society. It was during this period that the future paths of art began to be more clearly defined, and this was recognized by the figures of art and literature themselves - witnesses or participants in formidable social events of the early XX century. "We were divided not only in 1917, but even in 1905, when I saw little and recognized little in my life" (Blok, 1955, p. 729), Alexander Blok wrote in a letter to Zinaida Gippius. The formation of two opposite types of art belongs to this period: socialist realism, based on proletarian ideology, and modernism, based on idealistic philosophical theories of the XIX and XX centuries.

\section{Conclusion}

The Marxist methodology is especially effective in the study of the sociological problems of art, when it comes to the laws of artistic culture development, the need to determine the effectiveness, prospects of a particular aesthetic phenomenon.

The high scientific value of the Marxist analysis for artistic phenomena, especially in their historical and social aspect, is now recognized even by bourgeois scholars. Thus, the "patriarch" of modern US theorists Thomas Munro wrote in an article specifically devoted to the role of Marxist theory in solving the problems of socio-economic determinism and the dialectics of processes and the history of their prenatal culture: "The ideas of Marx and Engels are so widespread in the social sciences that no one in this area cannot deny the 
universal duty to them" (Munro, 1960, p. 430). No less important, argues T. Munroe, is the teaching of Marx and Engels for the school of scientific knowledge for the social foundations of artistic culture in its historical development: "They were the first to clearly establish and develop a general concept of the economy impact on the culture development. The fact of this impact, exerted to a greater or lesser extent, is now recognized by scientists in sociology and world history. But, recognizing the purely scientific depth of Marxist ideas, T. Munroe is trying to neutralize the revolutionary orientation of Marxism and especially Leninism, which poses an obvious danger to modern bourgeois theorists of culture. To this end, he contrasts Lenin with Marx, seeking to find "the difference between the views of Marx and his main followers in this area" (Munro, 1960, p. 423).

Having made a forced concession, recognizing the convincing nature of Marxist analysis in relation to the social problems of the past, Munro resolutely opposes the Marxist-Leninist class approach to the phenomena of contemporary art. He accuses the Marxists of "over-simplifying" history, of "reassessing the class struggle as a factor in influencing art." He expresses his rejection of Soviet theory and practice of art, and extends to the field of art culture the concepts of "attenuation" of the class struggle and convergence in the field of ideology widely propagated in the West. T. Munroe declares a consistent Marxist analysis of the social problems for artistic culture as dogmatism and, in contrast, aggressively promotes pluralism in ideology. Thus, T. Munroe remains essentially in his idealistic philosophical positions, and the "appeal" to the "fashionable" Marxism in the West now serves as a means for him to "renew" his early, losing popularity ideas (Munro, 1960, p. 455).

Getting to the scientific understanding of the complex and complicated phenomena of modern art culture, it is necessary to reveal not only the socio-economic reasons for their appearance; the philosophical prerequisites for the development of modern bourgeois art, the ideological orientation of its movements should be identified.

Having experienced the influence of philosophical idealism, various directions of modernist art in the process of evolution in the XX century, they did not change the ideological essence, only the arrangement of accents in favor of one form or another side or trait of idealism changed. So, in the 1920s, the fascination with Schopenhauer, Bergson and Nietzsche was replaced by an increased interest in Kierkegaard, whose ideas were "updated" by K. Jaspers and M. Heidegger and received with the active help of A. Camus, J.-P. Sartre and other bourgeois theorists have the widest circulation in the bourgeois world called "existentialism" (Munro, 1960, p. 439). The neo-Freudians of various kinds began to propagate the modernized ideas of the Austrian psychiatrist in every way, using them to interpret history, culture, etc. The doctrine of the medieval scholastic Thomas Aquinas served as material for the creation of a "modern" system of aesthetic values, which aroused the interest of bourgeois figures. culture in connection with the spread of neo-Thomism in the West (Lunacharsky, 1967, p. 345).

Naturally, the philosophical idealist teachings and aesthetic systems that make up the theoretical foundation of modern bourgeois art, embodied in its various directions not directly but indirectly. Moreover, in one direction, there are often elements of various philosophical teachings: for example, in the art of absurdity, along with existentialist views that make up the philosophical basis of this direction, we find elements of Bergson's intuitionism and Freud's psychoanalysis.

An abstract consideration of the artistic creation techniques outside of the creative method is often used by bourgeois theorists of art and revisionists in the field of MarxistLeninist aesthetics in their attempts to "dissolve" realism in various areas of modernist art.

Only a Marxist analysis of artistic phenomena and techniques of artistic creation in their correlation with the creative method makes it possible to reveal the true interconnections of 
these phenomena and the essence of artistic techniques, allows us to discover and criticize scientifically based falsification ideas of bourgeois art theorists.

\section{References}

1. L.V. Lapoktysh, Criticism of bourgeois views on the social and aesthetic significance of "mass culture" (abstract of a dissertation on philosophy, specialty of the Higher Attestation Commission of the Russian Federation 09.00.04, 1984). Information on http://cheloveknauka.com/kritika-burzhuaznyh-vzglyadov-na-sotsialnoe-iesteticheskoe-znachenie-massovoy-kultury\#ixzz $5 \operatorname{shf} 12 \mathrm{~d} 3 \mathrm{~N}$

2. O.G. Jose, La deshumanizacion del arte (Obras Completas, t. III, Madrid, 1950).

3. A.G. Egorov, On the reactionary essence of modern bourgeois aesthetics (Moscow, 1962)

4. A. Blok, Op. in 2 volumes, 2, Moscow (1955)

5. I. Kulikova, Philosophy and the art of modernism (Politizdat, Moscow, 1974)

6. S. Melman, The Peace Rase. London. Murno, Th., The Marxist Theory of Art History. Socio-economic Determinism and Dialectical Process, The Journal of Aesthetics and Art Criticism, 4, (1960)

7. A.V. Lunacharsky, Art and its latest forms (Collect. in eight volumes, v. 7, Moscow, 1967) 